\title{
Engaging ESP University Students in Flipped Classrooms for Developing Functional Writing Skills, HOTs, and Eliminating Writer's Block
}

\author{
Ashraf Atta M. S. Salem ${ }^{1}$ \\ ${ }^{1}$ Department of Languages, College of Management Sciences, Sadat Academy for Management Sciences, Egypt \\ Correspondence: Ashraf Atta M. S. Salem, Department of Languages, College of Management Sciences, Sadat \\ Academy for Management Sciences, Alexandria.
}

Received: October 15, 2018 Accepted: November 18, 2018 Online Published: November 22, 2018

doi: 10.5539/elt.v11n12p177 URL: https://doi.org/10.5539/elt.v11n12p177

\begin{abstract}
The current study aims to investigate the impact of using flipped classroom approach on improving functional writing skills of business majors. Also, it aims to enhance some Higher Order Thinking (HOTs) skills including analysis, evaluation, and creation. Additionally, the study may help in eliminating writer's block of the study sample. A standardized functional writing skill Pre and Posttest, Higher Order Thinking (HOTs) skills test and writer's block questionnaire have been used to assess the target gains of students at the end of the study. The Quasi-experimental research design was used to investigate progress achieved by the sample of the study which included (51) business majors; (26) business students for the experimental group and (25) for the control group. The findings revealed large gains in functional writing skills, HOTs in favor of experimental group compared with the control group with minimized writer's block based on the T-test differences in scores. Also ANOVA statistics among the quizzes targeted individual skills during the experiment showed on-going progress in both targeted skills and reduced writer's block. It is recommended that flipped learning approach should be used in language learning practices.
\end{abstract}

Keywords: flipped classroom, functional writing skills, HOTs, writer's block

\section{Introduction}

For decades and across different cultures, teaching methods used in the university level were the same, it depends mainly on the traditional formal lectures teachers deliver, or as King's (1993) envisages "a sage on the stage" as he/she represents the sole source of knowledge which students passively receive. Traditional teaching methods which were delivered through lectures have been criticized due to the following reasons: students are passive listeners for lectures without getting an opportunity to think of information provided, also, students have to memorize and retrieve information for the testing purposes. Second, teachers in traditional lectures do not consider learners individual differences, low-achievers are straying now and then catching pieces of information while missing other, meanwhile, high achievers feel bored when they listen to the same information repeated over again. Hence, traditional lectures are not a good match to improve thinking skills, especially higher order skills (HOTs) which include application, analysis and evaluation (Bonwell, 1996; Huxham, 2005; Young, Robinson, \& Alberts, 2009).

Despite the drawbacks of traditional teaching methods, it still works well with certain materials, teaching situations, and certain students. Therefore, the widespread of computer in education and web based tools for the purposes of teaching and learning do not minimize the significance of traditional teaching environments. However, computer based leaning (CBL) and later web-based Learning (WBL) maximize students' involvement and engagement. Effective integration of traditional teaching methods and computer assisted language learning enhances the learning experiences, it also maximizes student's engagement which provides entertaining learning experiences through well designed learning environments.

The use of web based learning and digital learning tools such as streaming videos, collaborative discussions, readings, has drastically changed teaching and learning practices. It effectively helps students to lean themselves through self-study tools; Youtube tutorials, independent courses and MOOCs (Senske, 2017), these online open resources provide lower-cost and more accessible sources of learning materials compared with traditional 
teaching (Hyman, 2012). However, these teaching materials are effective for self-study, it should be verified for use inside the classroom for more formal schooling experiences (Bergmann \& Sams, 2012). Blending online and offline materials refers to flipping learning practices. Flipping learning or flipped classrooms involves inverting the traditional premise that "knowledge is taught at class and homework is done outside class" (Zhou \& Zhang, 2017). In higher education institutions, the limited learning resources represent a driver for universities to adopt flipped classroom, two-thirds of universities use lecture-capture software to support flipped classroom (Straumsheim, 2013).

Blended learning is one of the common approaches that made use of the shiny aspects of both traditional teaching methods and online and digital learning tools. Prior studies investigated the impact of blending traditional teaching and online learning approaches on enhancing students' academic achievement and their skills. One of the latest blending trends is to flip the teaching/learning practices. Flipped learning is a relatively new term and it has no decisive definition (Johanson \& Cherry-Paul, 2016). Several terms have associated with the flipping process; flipped learning, flipped classrooms, inverted learning, or turning learning upside down. Although scholars believe deep that flipped learning denotes flipping teachers, flipped learners, flipping teaching practices, the researcher views that the essence of the flipped learning is the process of changing focus. The main focus of the traditional teaching was on what teachers can do inside the classroom, teachers are the pivot upon around which the whole educational process revolve. These teaching practices is referred to as teacher-centered approach which is contrasted with the learner-centered approach that relates with active participation of students in their own learning. Therefore, it is clear that flipped classrooms associates with a "focus change" form teacher-centered approach into the learner-centered approach. It includes changing the teaching/learning practices from inside the classroom into a more wide self-learning environment which depends on the use of out-of-the class learning materials and resources. In addition, flipping learning or "focus-changed learning" does not only help changing the focus learning process, it also includes redefining both the teachers' and learners' roles. Additionally, flipping also change learner's tendencies and attitudes towards teaching/learning experiences. Therefore, flipping indicates changing learner's attitudes from being passive listeners to materials teachers present into active participants who are eager to learn, students are easily involved and engaged in the learning process.

Researchers and practitioners - especially in the Arab countries and Middle East - view flipped learning as a univariate teaching strategy with the same procedures and practices. Rather, flipped learning is a blended learning teaching approach with several teaching models, among these flipping models are: standard inverted classroom, discussion-oriented flipped classroom, demonstration-focused flipped classroom, faux-flipped classroom, group-based flipped classroom, virtual flipped classroom, and flipping the teacher.

Although there is no single model of flipped classroom (Tucker, 2012), the flipped classroom is characterized by common course structure: instructional content that precedes class lectures to be done as an assignment before coming to the classroom, in-class time that is mainly assigned for problem-solving activities and advanced concepts which are dealt with to help engaging students in collaborative learning experiences (Findlay-Thompson \& Mombourquette, 2014; DeLozier \& Rhodes, 2016). Researchers and in-field educators have advocated flipped learning lectures based on active learning philosophy, among these models is a technology-mediated interactions (Beekes, 2006; Rosie, 2000), others are technology-free enhanced lectures (Bonwell, 1996).

\subsection{Study Objectives}

The current study aims to investigate the effectiveness of implementing flipped learning approach on developing business English college students' performance in functional writing skills, enhancing higher-order thinking skills (analyzing, evaluating, and creating). It is also aimed to assess the usefulness of the developed functional writing skills and enhanced HOTs skills on eradicating writer's block of those students.

\subsection{Study Problem}

College students majoring in business do not need only to be competent in their field of specification, but they also need to be proficient in English for business purposes (ESP). Business non-English majors are required to use English language skills proficiently at the workplace. Upon joining work, they need to communicate effectively both in spoken and written language.

ESP is designed to meet specific needs of certain group of learners to cope with their work requirements, thus, it is a work oriented discipline. It makes use of underlying methodology and activities of the discipline it serves. Besides, it is centered on the language (grammar, lexis, and register), skills, discourse and genre appropriate to these specific activities. 
The scores of third year business majors in the previous two years in Business English stimulates the researcher to conduct a pilot study which consolidated his guesses. This premise coincides with the fact that traditional teaching strategies revealed less effectiveness in developing language skills in general and business English in particular. Meanwhile, blended learning approach indicate effectiveness in developing academic achievement, improving skills and creating positive attitudes. Flipped learning approach has shown to be an effective teaching/learning tool to teach general English (e.g. Webb \& Doman, 2016; Kvashnina \& Martynko, 2016; Sun, 2017; Sung, 2015; Filiz \& Benzet, 2018; Li \& Swanthep, 2017; Singh et al., 2017), developing writing skills (Guvenc, 2018; Vitanofa \& Anwar, 2017; Ahmed, 2016; Ayon, 2017), in teaching ESP students (Kirk \& Casenove, 2015; Lee, 2017), and teaching business English in particular (King \& Piotrowski, 2015).

Several evidences have been accumulated to support the usefulness of flipped learning as a good means to develop business majors' English language skills, especially functional writing skills due to its importance in their work environments. In addition, flipping learning or rather say changing process focus; from teaching to learning, from teacher-centered to learner-centered, from passive listening to lectures to active participation in designing materials to be used, and from targeting LOTs (Lower-order thinking skills) to enhancing HOTs (higher-order thinking skills). Therefore, it is thought that flipping the traditional teaching classes into interesting learning sessions is effective in developing thinking skills, especially HOTs especially in the developing countries in Africa and MENA due to the scarcity of resources and school facilities. Also, it should be considered that educational systems in the developing countries rarely pay due attention to enhance these high level skills and to create positive attitudes towards learning.

Notably, traditional teaching approaches university teachers adopt through the use of lectures they deliver may be effective to develop lower-order thinking skills (LOTs) such as remembering, understanding, and application. On the contrary, blended learning approaches has shown to be effective on enhancing Non-English major's language competencies. Therefore, writers who develop their LOTs and decreased skills usually face certain block moments or times when writers stop for hours without writing a single word although they possess developed writing skills. Therefore, flipped learning has shown to be effective on developing thinking skills, it enables writers to overcome moments of writing blocks they may encounter inside or outside the class.

\subsection{Study Hypotheses}

The current study tries to test the following hypotheses:

1) There are statistically significant differences in the mean scores of third year business majors between the experimental and control groups in their functional writing skills in favor of the experimental group.

2) There are statistically significant differences in the mean scores of third year business majors between the experimental and control groups in their higher-order thinking skills (analyzing, evaluating, and creating) in favor of the experimental group.

3) There are statistically significant differences in the mean scores of third year business majors between the experimental and control groups in their levels of writing block in favor of the experimental group.

\subsection{Relevant Scholarships}

\subsubsection{Flipped Classroom}

Flipped classroom involves innovative ways of content delivery, it includes taking content normally delivered inside the classroom through traditional lectures to the outside the classroom through open access online materials. Flipping learning includes inverting the place, timing and ways of content delivery. Therefore, assignments and homework that would typically assigned to learners to do at home are dealt with inside the classroom.

Instructional content of the taught discipline has been out-of-class instead of the traditional model which depends on in-class lectures as the main form of teaching. Pre-class activities beside in-class tasks help instructors to save more time for one-on-one interaction with individual students get involved and engaged (Roehl et al., 2013; White et al., 2017), more important, learning through flipped classroom consolidate learner's autonomy. According to McLaughlin et al. (2014), flipped classroom approach includes student-centered teaching practices which allow learners to improve their high level thinking skills such as analytical skills, problem solving skills, critical thinking, and creative thinking skills. Students practice these high leveled thinking skills in deep learning, lifelong learning, self-directed learning, reflective learning that enhances students' motivation levels and creates positive attitudes (Lestari \& Widjajakusumah, 2009; Indrianti, 2012; Al-Zahrani, 2015; Nouri, 2016; Wang \& Wang, 2017). Hence, implementing flipped learning approach in ESP contexts represents a response to sustainable development of education initiatives appropriate for English language learning (Emaliana, 2017) 
It is worth noting that flipping classrooms is not a super-hero teaching strategy, it helps to enhance teachers to guide and learners to lead. Flipping learning includes pre-class exploration and explanation and in-class elaboration for active learning. Flipping learning saves teachers' time and effort for more interaction to take place between the two parties, especially in "inquiry-driven group work and discussion" (Senske, 2017). Time saved for in-class interactions provides students opportunities to ask questions and receive answers about the materials provided and to receive intermediate feedback about their inquiries. Unlike traditional teaching practices, flipped teaching sessions creates productive active learners instead of being passive listeners to lectures delivered.

In addition, flipped learning provides learners opportunities to learn at their own pace, it pays a due attention to the learners' individual differences. Most descriptions of the flipped classrooms suggest using multimedia recorded lectures so learners can watch as pre-class activities (O'Flaherty \& Philips, 2015). Multi-leveled students who missed certain steps in the lesson can replay recorded videos and clips at their own speed, it can improve their academic achievement, support their skills, and enhance their literacy skills on the run. According to Krathwohl (2002); Werner, Hanks, and McDowell (2004); Nouri (2016), flipped learning paves the way for active learning experiences as it engages learners in high level thinking activities that address the skills of application, analysis and synthesis. It also helps learners to develop problem-solving skills in a step to improve student's abilities to cope with daily life.

Moreover, flipped learning provides students with much more time for one-on-one interactions with their teachers during in-class projects. Intensive interactions provide teachers opportunities to be aware of students' attitudes and interests, eventually, to help producing positive attitudes (Senske, 2017). Bergmann, Overmeyer, and Willie (2011) list other advantages of flipped classroom; development of life-long learners, increased engagement in the taught materials, and increased interactions between students and faculty. Stone (2012) emphasizes the importance of freeing class time through watching recordings at home, it clarifies difficult concepts and create connections between taught materials inside the classroom and everyday life situations.

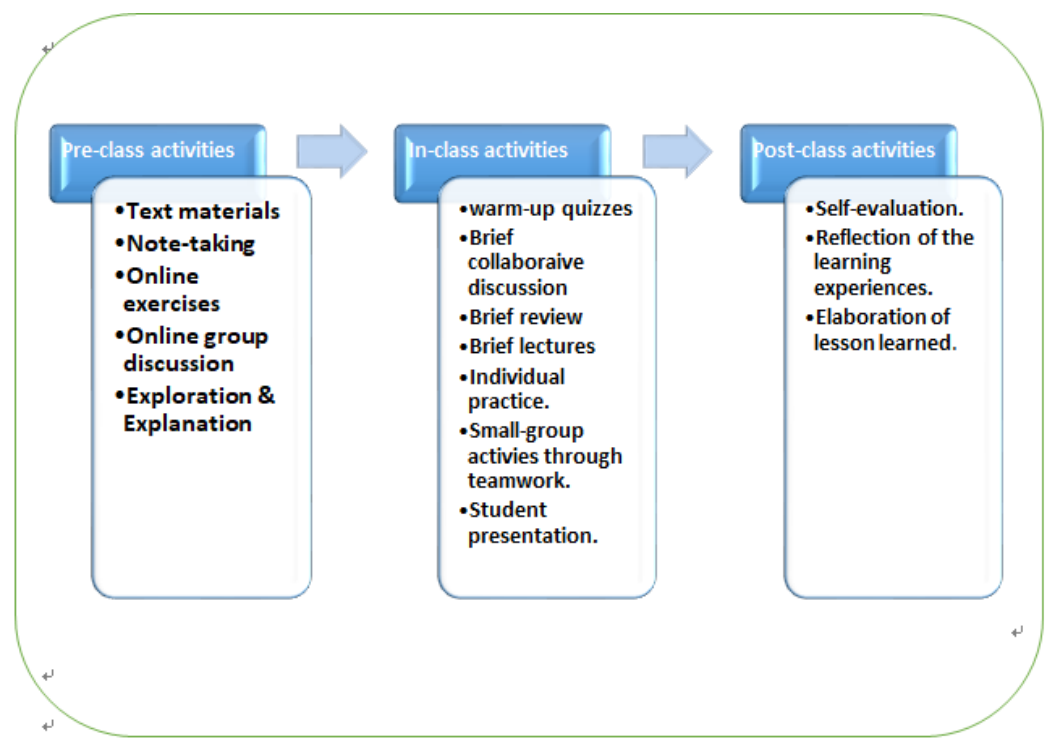

Figure 1. Components of flipped learning

Flipped learning is a rather new teaching approach in higher education institutions, however, some empirical research has been conducted to assess the impact of using flipped classroom in language learning.

\subsubsection{Functional Writing Skills}

Writing as one of the four basic language skills, is given a unique importance. The value of writing is confirmed by research, it is of great value for academic as well as occupational purposes. Writing is a valuable tool for communicating one's thoughts to others. It helps to both promote the sense of ownership and express his inner feelings. Writing is the commonest way of assessing students' performance in English (Salem, 2008).

According to Heaton (1994), writing skills are complex and sometimes difficult to teach, requiring mastery not only of grammatical and rhetorical devices but also of conceptual and judgmental elements. The writing process 
includes varied skills necessary for writing well in terms of language use, mechanical skills, treatment of content, stylistic skills and judgmental skills. English language learners need to develop their writing skills to foster their understanding. Speaking and listening skills are easier to be acquired -through conversation- than writing and reading.

Writing skills are strongly enhanced when instruction is explicitly designed to address students' needs. Writing is one of the main important devices for people to express themselves, to shape ideas, to persuade and convince others (Gracey (2004). There has been an increasing concern to teach writing since it is a useful tool for learning (Abolyosr, 1996). Functional approach to language learning in general and writing specifically focuses on developing writing through communication. It ensures using language to achieve certain purposes, it supports using language meaningfully (Hartnett, 1997).

Halliday (1994) was the investigator of the systemic functional linguistics. In his point of view, language accomplishes what systemic functional linguistics calls three malfunctions of language: to express ideas, to enact social relations, and to create specific discourse or texts. To some extent, every communication process does all three, they influence choices of content and form.

Several evidence of the importance of developing functional writing skills can be traced back to earlier time. One of the studies is the one conducted by Korbel (2001). The study aims to develop a teaching program to increase the functional writing ability and to improve the attitude of sixth grade students. Evidence of the problem was established through a student survey, teacher questionnaire, and student writing samples. Analysis of probable cause data indicated that there are three possible reasons of the lack of functional writing skills. The school environment lacked curriculum, time allotment, and sufficiently trained staff members. No parent model and increased technology and time constraints were daily influences. The students themselves contributed to the deficiency due to their lack of interest, low expectation, and fear of difficulty. A review of the solution strategies, suggested by other experts in the field combined with an analysis of the problem setting, resulted in the development of a safe environment that would promote a positive attitude toward writing, devoting time daily to provide a multitude of writing experiences, and mini-lessons that would be target specific writing weaknesses. Post intervention data indicated positive gains in writing capabilities, increased ability to self-monitor and evaluate, and a more positive attitude toward s the writing process.

In addition, Salem (2013) conducted a study that investigated the impact of using writing workshop approach on developing functional writing skills of pre-service teachers of English in Hurghada faculty of Education. For that purpose, a teaching program based on the writing workshop approach, checklist of the skills and sub-skills of functional writing skills, and pre-posttest of functional writing skills were constructed and validated. The sample of the study was forty prospective teachers of English in Hurghada faculty of Education. Findings of the study indicated the writing workshop-based program had significant effects on improving the subjects' functional writing skills.

Functional writing skills related to business majors include skills students need in their university study such as writing formal writing reports, skills necessary immediately after graduation and prior to joining work such as writing CVs \& resumes and skills necessary at their workplace such as writing agenda \& minutes of meetings. ESP business major's functional writing skills differ from those EAP skills that include letter writing, report writing, writing biography, and outlining.

\subsubsection{Higher Order Thinking Skills (HOTs)}

People do not think spontaneously, they are evoked through facing certain problems and questions, or by complexities and confusion (Dewey, 1933). Thus, it is important to develop teaching materials that revolves around certain problems, a group of questions, or perplexing situations. According to King (1997), encountering unfamiliar/difficult problems, uncertainties, questions or dilemmas activates students' ability to think at higher levels. It encourages students to use their critical thinking and creative thinking skills to overcome these problematic situations.

Thinking skills fall into two main categories, namely, lower-order thinking skills and higher-order thinking skills (Pohl, 2000; Anderson et al., 2001). Lower-order thinking skills (LOTs) refer to thinking skills which do not require high level of thinking, whereas, higher-order thinking skills (HOTs) include applying high levels of thinking such as synthesizing, evaluating, and creation.(Margana \& Widyantoro, 2017).

HOTs also cover four main higher skills namely, critical thinking, problem solving, decision-making, and creative thinking skills (Lewis \& Smith, 1993). Additionally, it includes critical, logical, reflective, metacognitive, and creative thinking skills (Singh et al., 2018). Based on Bloom's Taxonomy (Bloom et al., 1971) 
of educational objectives, high level thinking skills include the upper three levels of cognition: a) Analysis that emphasizes breakdown of whole concept or idea into minor parts and identifies the relationship between parts and the whole, b) Synthesis which helps putting parts together to form a whole and focuses on the way of constructing such a whole, and c) Evaluation which refers to making judgments about the value of ideas or materials using criteria and standards (Zohar, Degani, \& Vaaknin, 2001; Marzano \& Kendall, 2006; Lee Allen \& Wern, 2011; Naraynan \& Adithan, 2015). These levels are commonly used in activities such as problem solving, reasoning, thinking, assessing and concluding (Bloom, 1956; Anderson et al., 2001; Zohar \& Dori, 2003; Yunos et al., 2010).

Developing thinking skills is important especially nowadays (Fahim \& Masouleh, 2012; Yang \& Gamble, 2013), yet improving high level thinking skills is not an easy task. Thinking skills represent an essential tool for learners to compete in the global competitive challenge that characterizes the digital age (Ganapathy \& Kaur, 2014; Chen, 2016). Questioning is one of the main teaching techniques that help improving higher order thinking skills, yet other researchers (Steven, 1912; Rowe, 1974; Wu, 1993) believe that questioning include several drawbacks, one of which is that it is not a one sized teaching strategy that fits all.

\subsubsection{Importance of HOTs}

Traditional teaching rarely render students the ability to apply knowledge they acquired in the classrooms in daily situations (Bennett, Lubben, \& Hogrth, 2007; Raub et al., 2015).Therefore, less emphasis is laid on improving HOTs which adversely affects student's ability to apply knowledge they acquire outside the academic institutions (King, 2009). Due emphasis should be placed on improving high levels of thinking to promote cognitive skills such as critical reasoning skills as well as creative thinking (King \& Ritchie, 2012).

The value of higher order thinking is reflected in L2 education (Chen, 2016), for example, business English students target improving the four language skills including listening, speaking, reading and most importantly writing. It comes true encouraging those students to use high thinking skills of reasoning, evaluating, and problem-solving to communicate their thoughts, ideas and opinions, whether spoken or written, critically and creatively. Written products represent an output of recursive outlining, composing and revising processes through critical, logical, reflective, metacognitive, and creative thinking skills.

Curriculum designers should put in mind designing teaching materials around daily life problems, confusing situations, and deep questions. Teachers should use every teaching situation to encourage learners to reflect on the situations and problems. According to King, Rohani, and Goodson (1997), effective teaching strategies and suitable learning environments help facilitating the growth of HOTs through improving student's persistence, self-monitoring, open-minded and flexible attitudes.

Creative insights should be used to solve extreme difficult problems (Rajendran \& Idris, 2008), developing HOTs should be emphasized to facilitate solving such problems (Chinedu, Kamin, \& Olabiyi, 2015). Students should be encouraged to apply high level thinking skills to solve problems and decode the confusing situations (Yee et al., 2011). HOTs are viewed as a thinking function of learner's minds to cope with challenging situations. Nevertheless, HOTs may be easy to develop for some students not for others, hence, consensus for creative and cultural education is crucial (Robinson et al., 1999; David, 2008; Thomas \& Thorne, 2009).

\subsubsection{Teaching Strategies for HOTs}

Developing high level thinking skills can be duly achieved through designing and implementing suitable teaching material side by side with effective teaching strategies (Stroupe, 2006; Ganapathy et al., 2017). Higher education institutions do not consider developing thinking skills to the degree required especially with the emergence of emerging technologies in the light of increasingly complex global human relations (Petko, 2012).

Therefore, leveraging ICT into high level thinking skills development can provide Generation "Y" learners with an optimum learning state (Ganapathy et al., 2017). It has been confirmed that it is possible to promote HOTs through ICT integration in language learning in general (Surban, 2011; Ali, 2012; Majumdar, 2015), and teaching writing skills in particular (Razak \& Lee, 2012). Additionally, using innovative learning strategies such as active learning and problem-based learning (PBL) effectively develop HOTs through promoting communication, problem-solving and self-directed skills (Othman \& Mohammed, 2014). ICT integration in the process of language learning not only help promoting thinking skills in general and particularly HOTs, it also increases students' motivation in learning (Voogt, 2008). It is facilitated through teacher's incomparable success in diversifying teaching materials and activities that help students to engage in active learning processes.

According to Thomas and Thorne, (2009), lessons designed to improve higher order thinking skills should include: 1) concepts that refers to an idea around which a group of ideas revolve, 2) schemas, learning is the 
making of meaning that derived from making connections of concepts, 3) metaphors, similes and analogies as a way to abstract or unfamiliar concepts, 4) visualization of ideas and concepts that is so important to promote students' thinking skills, and 5) inference that refers to the students' ability to draw conclusions from evidence and a set of facts. Scholars emphasized the distinguished features of HOTs (Lopez \& Whittington, 2001; Krathwohl, 2002; Miri, David, \& Uri, 2007; Pickard, 2007; King et al., 2011; Yee et al., 2010; Yunos et al., 2010; Yee et al., 2011; Lucas, Spencer, \& Claxton, 2012). Hence, teaching strategies that helps improving higher levels of thinking skills can be summarized as follows:

1). Take the mystery away and teach the concept of concepts

2). Teach concept of concepts

3). Name and categorize concepts

4). Move from concrete to abstract and back

5). Teach inference and connect concepts

6). Teach question-answer relationships

7). Include brainstorming activities in the lessons

8). Use teaching techniques that provokes higher thinking levels

9). Emphasize feedback generation for students (Chinedu, Kamin, \& Olabiyi, 2015).

\subsubsection{Writer's Block}

Writer's block is a phenomenon that is difficult to explain, it is a mysterious composing problem. Writers may be able to write fluently one day, yet the next day he/she sits helplessly staring at the page. Writer's block represent a problem for writers, it is misunderstood by instructors that writers got stuck, yet sometimes it represents a while to think about the writing task (Baker-Brodersen, 1988). According to Jensen (1984) the writer's block seems to be puzzling as it happens for even bright and skilled writers. Positive blocks representing terrifying delay usually precedes effective pieces of writing. Competent writers may also spend considerable time to finish a writing project without completing the task, the same writer may suffer a current writer's block while not suffering serious blocks in the past.

Writer's block may return back to the lack of planning and a lack of planning to edit. Without due planning or outlining, writers will have no ideas to write about. Ideas are the raw material of the writing industry, thus, fruitful generated ideas minimizes the opportunities of writer's blocks to occur. According to Rose (1984), writer's block is defined as "an inability to begin or continue writing for reasons other than a lack of basic skill or continue writing for reasons other than a lack of basic skill or commitment.”(p. 3).

The essence of writer's block can be traced back to the early 1980s with the works of Mike Rose (1980) who views writer's block may be rested in the emotional realm through anxiety, fear of evaluation, insecurity, etc. It may be resulted from variation in cognitive style. Additionally, blocking may be originated in the melting of both emotion and cognition. Healy (2010) emphasizes that with no effective plan to edit, each sentence is crushed under the weight of perfection: over sense of perfectionism may cause blocks to writer, with only one draft each word, sentence, and paragraph must be perfect to be displayed on the paper. Therefore, ending writer's blocks can be achieved through three main steps: planning and outfling, just write it, and editing beyond spell-check.

Therefore, the first main technique to alleviate writer's block is to encourage writers to plan the writing task through using graphic organizers and visuals. Using charts especially at this stage helps writers to list the facts, holdings and reasoning from each case, also charts can effectively help them compare and contrast the case task. Derived from the main concern of the current research in functional writing, for some memos, writers should create an outline using certain formats. Another technique is to go ahead to the actual writing process, this should spend one third of the whole writing process. Finally, proofreading and editing occupy the last phase of writing, this stage can be sub-divided into other steps based on the writers' levels.

It is worth noting that when a writer's mind fluctuating in doubt unable to move pen on a paper, it is unlikely that "information about the entwined strands of mental disease and creative writing will help the writer to preserve." (Flaherty, 2004). Writer's block may exaggerate when writing business English, the twin difficulty here is the lack of technicalities and the shortage of mechanics. 


\section{Methods}

\subsection{Participants}

The participants were undergraduate students $(n=51)$ in the third year business administration in the College of Management Sciences (CMS), Sadat Academy for Management Sciences (SAMS), Egypt. CMS accepts short-listed candidates to be enrolled in the credit-hour programs. Therefore, participants are (51) business majors; (26) business students for the experimental group and (25) for the control group. All participants registered credit hours in the fall semester in the academic year 2017-2018. The students, 18 females and 33 males, ranged in age from 18 to 21 years, with a mean age of 19.50 years $(\mathrm{SD}=.09)$. Out of the 51 students only 3 had a previous experience of flipped classroom.

\subsection{Measures}

\subsubsection{Functional Writing Skills Test}

The Functional Writing Skills Test (FWST) aims primarily to assess the writing performance of Business English Students at the college of Management Sciences, banking section. FWST falls into four main sections; writing business reports \& Proposals, writing business emails, writing agenda \& minutes, and writing CVs \& Resumes. Total scores of FWST is 100 points divided into four main parts, 25 points each. Different question types were used in the FWST, it includes multiple-choice questions, open-ended questions, and essay (free writing) questions. Students' answers to the FWST questions reflect their performance in functional writing tasks. It is also denoted that the test design pays a due attention to the up-to-date design depending on web-based tools to cope with proposed teaching strategy, the flipped leaning approach.

Close inspection of Table 1 revealed that the reliability coefficients of the FWST questions and the total test score are good enough to rely on the test as a reliable measure of functional writing skills of CMS business majors.

Table 1. Reliability coefficients of FWST

\begin{tabular}{llll}
\hline Test Questions & & Cronbach's Alpha & Cronbach's Alpha Based on Standardized items \\
\hline writing business reports & $\&$ & .714 & .972 \\
Proposals & & \\
writing business emails & .630 & .981 \\
writing agenda \& minutes & .631 & .978 \\
writing CVs \& Resumes & .558 & .968 \\
\hline
\end{tabular}

Correlation coefficients denoting internal consistency displayed in Table 2 are relatively high to the degree referring to the test validity. According to Drost (2011), test validity is concerned with the meaningfulness of test components, when researchers measure behaviors, they are concerned with whether they are measuring what they intended to measure or something else. Therefore, it is clear that the test is valid i.e. it can accurately assess performance of business majors in functional writing skills.

Table 2. Internal consistency coefficients of FWST

\begin{tabular}{ll}
\hline Test Questions & Cronbach's Alpha \\
\hline writing business reports\& Proposals & .714 \\
writing business emails & .630 \\
writing agenda \& minutes & .631 \\
writing CVs \& Resumes & .558 \\
\hline
\end{tabular}

\subsubsection{Higher-Order Thinking Skills Test}

Higher-order thinking skills refer to the three high leveled of Bloom's Taxonomy of cognitive objectives; analysis, evaluation, and creation. Therefore, the main aim of the HOTs test is to assess the level of business English college students' performance of higher-order thinking skills, namely; analyzing, evaluating, and 
creating. The HOTs performance test falls into three main parts: part 1 assesses the students' performance in analyzing tasks into its components, it includes 5 main open-ended questions. Part two questions assesses the level of students' performance to evaluate and judge the evidences and tools that make better pieces of business writing. Open-ended questions in the third part assesses the students' ability to create new and unusual products that support the quality of business writing. The total score of HOTs performance test is 75 points, divided into three components, 25 points each.

Table 3 shows that the higher-order thinking skills test designed for the purpose of the study is reliable and it can - with confidence - assess the business students levels of HOTs in the context of ESP activities and tasks.

Table 3. Cronbach's Alpha reliability confidents of HOTs

\begin{tabular}{|c|c|c|c|c|}
\hline Scale Dimensions & Cronbach's Alpha & $\begin{array}{l}\text { Cronbach's Alpha } \\
\text { Based on } \\
\text { Standardized items }\end{array}$ & $\begin{array}{l}\text { Corrected } \\
\text { item-total } \\
\text { correlation }\end{array}$ & $\begin{array}{l}\text { Cronbach's Alpha } \\
\text { if item deleted }\end{array}$ \\
\hline Analysis & .74 & .96 & .92 & .83 \\
\hline Evaluation & .76 & .96 & .89 & .82 \\
\hline Creation & .71 & .97 & .91 & .82 \\
\hline
\end{tabular}

Correlation coefficients displayed in Table 4 reveal that the skills targeted in the HOTs test can be measured accurately without the fear of assessing other unnecessary skills that may overlap with the target skills.

Table 4. Internal consistency confidents of HOTs

\begin{tabular}{|c|c|c|c|c|}
\hline Scale Dimensions & Cronbach's Alpha & $\begin{array}{l}\text { Cronbach's Alpha } \\
\text { Based on } \\
\text { Standardized items }\end{array}$ & $\begin{array}{l}\text { Corrected } \\
\text { item-total } \\
\text { correlation }\end{array}$ & $\begin{array}{l}\text { Cronbach's Alpha } \\
\text { if item deleted }\end{array}$ \\
\hline Analysis & .74 & .96 & .92 & .83 \\
\hline Evaluation & .76 & .96 & .89 & .82 \\
\hline Creation & .71 & .97 & .91 & .82 \\
\hline
\end{tabular}

\subsubsection{Higher Order Thinking Skills Observation Sheet}

The HOTs skills observation sheet was primarily designed to assess the business college students' level of skills mastery. Therefore, the observation sheet helps instructors to judge the students' level of mastery of three main higher-order skills; analyzing, evaluating, and creating. It is composed of three main parts representing the three higher levels of Bloom's Taxonomy of the cognitive objectives: analysis, evaluation, and creation (synthesis), as they opposed the three lower-order thinking skills, namely, remembering, understanding, and application; The skills mastery is judged based on the 5 Lickert rubric; (4) excellent, (3) very good, (2) good, (1) poor, (0) absent. Each of the three parts in the HOTs observation sheet consists of twenty items, the total amount of items is sixty items with a maximum points of 240 and minimum of Zero. The lower the students' score in the HOTs observation sheet refers to lower skills mastery, whereas, the higher their scores, the better their skills mastery.

\subsubsection{Questionnaire for Identifying Writer's Block (QIWB)}

Questionnaire for Identifying Writer's Block (QIWB) was developed by Rose (1981). QIWB is an attitude questionnaire of 24 items that are divided into 5 subscales: Blocking (items 7, 9, 12, 16, 17, 22, 24), Lateness (4, $14)$, premature editing $(3,8,18)$, strategies for complexity $(5,11,15,19,23)$, and attitudes $(1,2,6,10,13,20$, 21).

If the test administers wish simply to identify only blockers, he/she can administer only the items within the behavioral subscales, blocking and lateness. If further, cognitive/behavioral and cognitive/attitudinal subscales can also be administered.

QIWP depends mainly on assumption that writer's block is not only an emotional response to fear of evaluation or self- revelation but instead reflects other cognitive difficulties, such as a lack of strategies for composing complex discourse or tendency to edit inappropriately early in the composing process. 
Table 5 revealed that QIWB reliability coefficients refer that the questionnaire is reliable upon multiple administration, therefore, it can be used to assess the levels of writer's block of CMS business majors with a considerable degree of confidence.

Table 5. QIWP Cronbach's Alpha reliability confidents

\begin{tabular}{|c|c|c|c|c|c|}
\hline $\begin{array}{l}\text { Scale } \\
\text { Dimensions }\end{array}$ & $\begin{array}{l}\text { No. of } \\
\text { items }\end{array}$ & $\begin{array}{l}\text { Cronbach's } \\
\text { Alpha }\end{array}$ & $\begin{array}{lr}\text { Cronbach's Alpha } \\
\text { Based ron } \\
\text { Standardized items }\end{array}$ & $\begin{array}{l}\text { Corrected } \\
\text { item-total } \\
\text { correlation }\end{array}$ & $\begin{array}{l}\text { Cronbach's } \\
\text { Alpha if item } \\
\text { deleted }\end{array}$ \\
\hline Blocking & 7 & .64 & .59 & .79 & .65 \\
\hline Lateness & 2 & .78 & .77 & .79 & .71 \\
\hline $\begin{array}{l}\text { Premature } \\
\text { Editing }\end{array}$ & 3 & .84 & .91 & .87 & .66 \\
\hline $\begin{array}{l}\text { Strategies for } \\
\text { complexity }\end{array}$ & 5 & .80 & .88 & .84 & .61 \\
\hline Attitudes & 7 & .68 & .63 & .54 & .84 \\
\hline Total & 24 & .74 & .76 & & \\
\hline
\end{tabular}

Table 6 reveals relatively good reliability statistics that refer to reliable assessment tools that can be relied on to assess the critical levels of writer's block business majors in CMS may suffer.

Table 6. Cronbach's Alpha coefficients if item deleted

\begin{tabular}{|c|c|c|c|c|c|c|c|c|c|}
\hline \multicolumn{2}{|c|}{ Blocking } & \multicolumn{2}{|c|}{ Lateness } & \multicolumn{2}{|c|}{ Premature Editing } & \multicolumn{2}{|c|}{$\begin{array}{l}\text { Strategies } \\
\text { complexity }\end{array}$} & \multicolumn{2}{|c|}{ Attitudes } \\
\hline $\begin{array}{l}\text { Item } \\
\text { No. }\end{array}$ & $\begin{array}{l}\text { Cronbach's } \\
\text { Alpha }\end{array}$ & $\begin{array}{l}\text { Item } \\
\text { No. }\end{array}$ & $\begin{array}{l}\text { Cronbach's } \\
\text { Alpha }\end{array}$ & $\begin{array}{l}\text { Item } \\
\text { No. }\end{array}$ & $\begin{array}{l}\text { Cronbach's } \\
\text { Alpha }\end{array}$ & $\begin{array}{l}\text { Item } \\
\text { No. }\end{array}$ & $\begin{array}{l}\text { Cronbach's } \\
\text { Alpha }\end{array}$ & $\begin{array}{l}\text { Item } \\
\text { No. }\end{array}$ & $\begin{array}{l}\text { Cronbach's } \\
\text { Alpha }\end{array}$ \\
\hline 7 & .62 & 4 & .57 & 3 & .81 & 5 & .75 & 1 & .31 \\
\hline 9 & .75 & 14 & .94 & 8 & .79 & 11 & .76 & 2 & .48 \\
\hline 12 & .59 & & & 18 & & 15 & .83 & 6 & .38 \\
\hline 16 & .63 & & & & & 19 & .73 & 10 & .64 \\
\hline 17 & .52 & & & & & 23 & .73 & 13 & .34 \\
\hline 22 & .60 & & & & & & & 20 & .32 \\
\hline 24 & .60 & & & & & & & 21 & .46 \\
\hline
\end{tabular}

Table 7 shows that the questionnaire is valid, hence, it is a reliable tool to assess the level of writer's block not any other constructs such as writing apprehension or writing anxiety which closely related with writer's blocks.

Table 7. Correlation coefficients of QIWP dimensions

\begin{tabular}{lll}
\hline Scale Dimensions & No. of items & Correlation coefficients \\
\hline Blocking & 7 & $.854^{* *}$ \\
Lateness & 2 & $.827^{* *}$ \\
Premature Editing & 3 & $.903^{* *}$ \\
Strategies for complexity & 5 & $.905^{* *}$ \\
Attitudes & 7 & $.455^{* *}$ \\
\hline
\end{tabular}


In addition, internal consistency correlations indicated the writer's block questionnaire to be valid based on the correlation coefficients between each item and the dimension it belongs to within the questionnaire. Evidences collected so far revealed that the questionnaire is both reliable and valid to assess the levels of writer's block of business majors in the third year college of management sciences.

Table 8. Internal consistency of QIWP

\begin{tabular}{|c|c|c|c|c|c|c|c|c|c|}
\hline \multicolumn{2}{|c|}{ Blocking } & \multicolumn{2}{|c|}{ Lateness } & \multicolumn{2}{|c|}{ Premature Editing } & \multicolumn{2}{|c|}{$\begin{array}{l}\text { Strategies } \\
\text { complexity }\end{array}$} & \multicolumn{2}{|c|}{ Attitudes } \\
\hline $\begin{array}{l}\text { Item } \\
\text { No. }\end{array}$ & $\begin{array}{l}\text { Correlation } \\
\text { coefficients }\end{array}$ & $\begin{array}{l}\text { Item } \\
\text { No. }\end{array}$ & $\begin{array}{l}\text { Correlation } \\
\text { coefficients }\end{array}$ & $\begin{array}{l}\text { Item } \\
\text { No. }\end{array}$ & $\begin{array}{l}\text { Correlation } \\
\text { coefficients }\end{array}$ & $\begin{array}{l}\text { Item } \\
\text { No. }\end{array}$ & $\begin{array}{l}\text { Correlation } \\
\text { coefficients }\end{array}$ & $\begin{array}{l}\text { Item } \\
\text { No. }\end{array}$ & $\begin{array}{l}\text { Correlation } \\
\text { coefficients }\end{array}$ \\
\hline 7 & $.47 * *$ & 4 & $.90 * *$ & 3 & $.521 * *$ & 5 & $.76^{* *}$ & 1 & $.74 * *$ \\
\hline 9 & $.34 * *$ & 14 & $.55^{* *}$ & 8 & $.67^{* *}$ & 11 & $.73 * *$ & 2 & -.42 \\
\hline 12 & $.60 * *$ & & & 18 & $.85^{* *}$ & 15 & $.74 * *$ & 6 & $.68 * *$ \\
\hline 16 & $.41 * *$ & & & & & 19 & $.82 * *$ & 10 & $.60 * *$ \\
\hline 17 & $.80 * *$ & & & & & 23 & $.92 * *$ & 13 & $.68 * *$ \\
\hline 22 & $.56^{* *}$ & & & & & & & 20 & $.83 * *$ \\
\hline 24 & $.55^{* *}$ & & & & & & & 21 & $.65^{* *}$ \\
\hline
\end{tabular}

\subsection{Materials and Procedure}

\subsubsection{Course structure}

The course focused on in this study prepares undergraduate business students for their university study as well as their workplace experiences. The learning objectives are on the one hand to facilitate students understanding of the functional writing skills that cover writing business reports \& Proposals, writing business emails, writing agenda \& minutes, and writing CVs \& Resumes, and on the other hand to familiarize students with higher order thinking skills that include application, synthesis and evaluation skills. Put differently, the course aimed at equipping students with conceptual knowledge related with the writer's block hand in hand with the effective strategies to avoid in order to use along the teaching course. See Figure 2 for the pedagogical structure of flipped writing sessions.

The course was divided into four main parts with four different examination tasks. The first part concerned writing business reports \& Proposals, it includes the types of business reports that include formal and informal reports, data-collection methods suitable for writing formal reports, and strategies used to analyze data collected. The pedagogical structure for this part comprised of models of poorly written business reports students are asked to restructure to as to sound organized. Students pre-writing endeavors were supported by three shorter recorded lectures (in average $15 \mathrm{~min}$ each), one traditional campus lecture (teacher presenting and summarizing the techniques of writing business reports \& proposals), and one interactive flipped classroom lecture in which the teacher presented examples of exam questions that students answered on their own through their own smart phones, tablets and computers. Teacher got immediate online formative feedback concerning the student's performance and the level of higher thinking skills, in turns, teachers provided students with elaborated expiations when needed. Additionally, teachers provided students with digital monitoring and supervision through a learning management system (Moodle). The examination for this part comprised of a multiple-choice digital exam in the learning management system. 


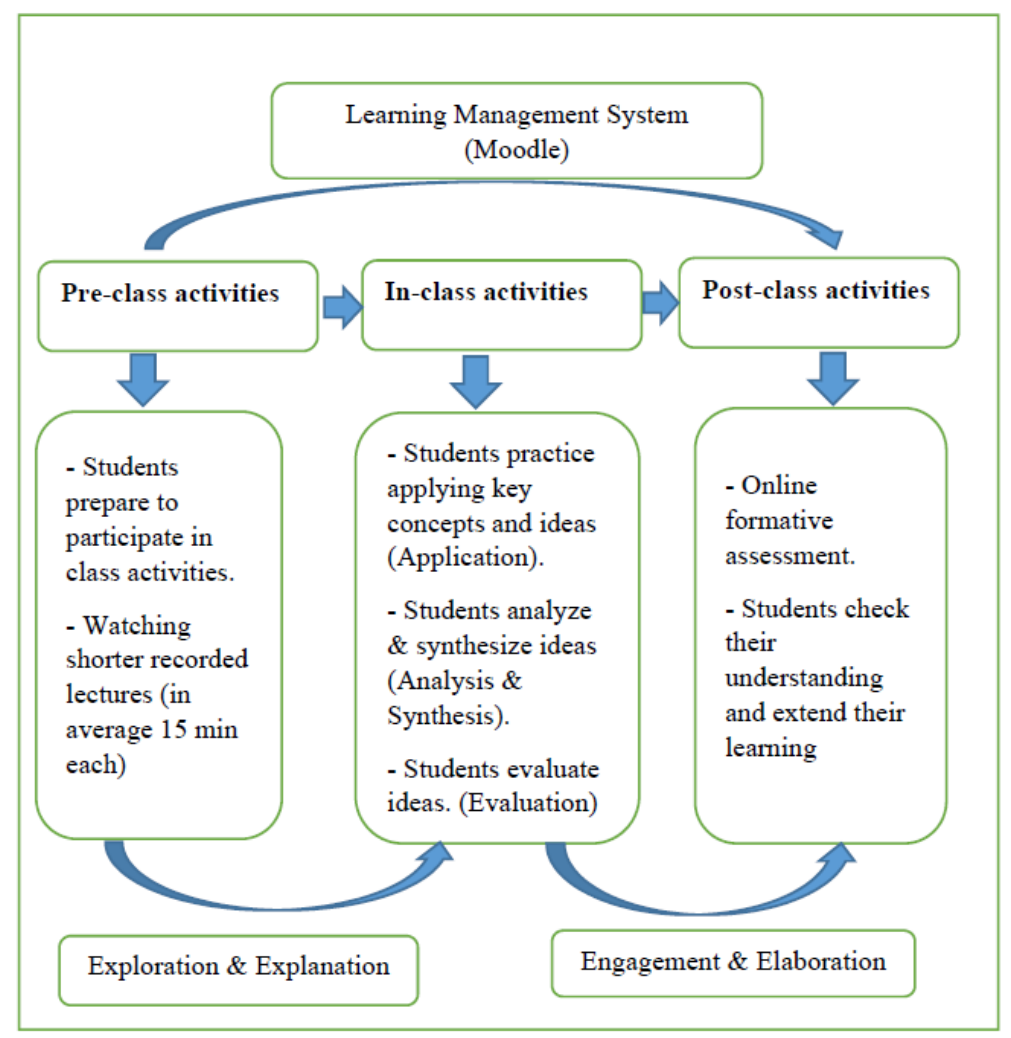

Figure 2. Pedagogical structure of flipped writing sessions

The current study adopts the Quasi-experimental research design, this design is used for studies that evaluate interventions but that do not use randomization. Like randomized trials, quasi experiments demonstrate causality between an intervention and an outcome (Harris et al., 2004). Two research groups are involved for the purpose of the study; the control group which does not receive any experimental treatment except for the testing procedures, students in the control group were taught using the traditional teaching approach, those students have not been exposed to the flipped learning experiences before. On the other hand, the experimental group has received experimental treatment including the use of flipped learning strategies including before class activities that depend on active and personalized learning. In this stage which coincides with the pre-writing phase, it usually occurs at home as a preparation for the subsequent stages. In this stage, students watch recorded clips on online platforms or stored videos in their digital devices as an endeavor to explore knowledge. The second stage includes in-class activities that increase student's motivation, involvement and engagement. In the flipped learning sessions, ending up a sessions does not imply the end of learning, a fellow-up activities occur after the formal schooling sessions finish. After class stage announces the beginning of successive rounds of self-study, students use digital tools and websites to consolidate knowledge understanding in the presence of teacher's supervision through different learning management systems to provide them with immediate summative feedback when needed.

\section{Results}

Flipped learning is considered as an instructional approach that depends on leveraging technology into usual teaching practices to make direct instruction available in individual sheltered learning environments instead of in formal schooling teaching settings. The basic fruits both teachers and learners harvest from implanting flipped learning compared with traditional teaching include saving classroom time for more discussions, motivating learners to work individually and in groups, and helping teachers' to effectively manage their classrooms.

Findings of this study duly coped with the beforehand mentioned premises, among which is that using flipped learning practices help learners to self-regulate their own learning. It enriches student's in-class performance due to the effective mental preparation prior to in-class tasks. Students rarely undertake such roles in the traditional classroom settings because of the dominating teachers' role, teachers are the lesson planners, the strict classroom managers and the sole knowledge provider. It is worth noting that traditional teaching is not an ineffective 
teaching approach, rather it is less effective teaching approach compared with up-to-date ones. It is still working well in certain teaching environments and with specific students populations. Traditional teaching practices may help learners to memorize information and data through the repetition processes teachers emphasized. Besides, it represents a good teaching aid for gifted and talented learners to understand and apply knowledge in other situations, yet, there has been no proven evidence for improving thinking skills. It has been shown that traditional teaching practices are lagging behind in the $21^{\text {st }}$ century with the widespread of modern innovations in sciences and technology.

Findings obtained from testing procedures of both testing groups beside the experimental treatment provided to the experimental group twined with the literature reviewed revealed relatively a good deal of improvement in CMS business students' overall performance. Business majors in the experimental group are supposed to achieve high in terms of their functional writing skills compared with their counterparts who receive no experimental treatment. Control group students receive teaching sessions using the traditional teaching approach. Table 9 shows the results obtained from statistical data analysis of control and experimental group students on the functional writing skills test.

Table 9. T-Test scores of control and experimental groups regarding functional writing skills

\begin{tabular}{lllllll}
\hline Functional writing Skills & Group & M & SD & F & t & p \\
\hline Writing business reports \& proposals & Control & 14.00 & 3.09 & .553 & 5.08 & .00 \\
& Experimental & 18.65 & 3.42 & & & \\
Writing business emails & Control & 15.44 & 3.12 & .185 & 4.04 & .01 \\
& Experimental & 18.84 & 2.89 & & & \\
Writing Agenda \& Minutes & Control & 15.92 & 2.97 & .186 & 4.02 & .00 \\
& Experimental & 19.30 & 3.04 & & & \\
Writing CVs \& Resumes & Control & 16.20 & 2.64 & .306 & 3.56 & .00 \\
& Experimental & 18.80 & 2.57 & & & \\
Total Scores & Control & 61.56 & 10.61 & .595 & 4.61 & .00 \\
& Experimental & 75.61 & 11.11 & & & \\
\hline
\end{tabular}

Close inspection of Table 9 reveals that non-English majors business students in the experimental group achieved relatively high gains in using functional writing skills compared with their counterparts in the control group in terms of writing business reports, writing business emails, writing meeting agenda \& minutes, and writing CVs \& resumes. Noticeably, business majors in the control group also achieved well when post-tested although no experimental treatment has been provided, the only intervention occurred is the traditional teaching practices. Yet, the use of flipped learning showed to be effective in improving academic achievement to a greater extent compared with other traditional approaches to teaching. 


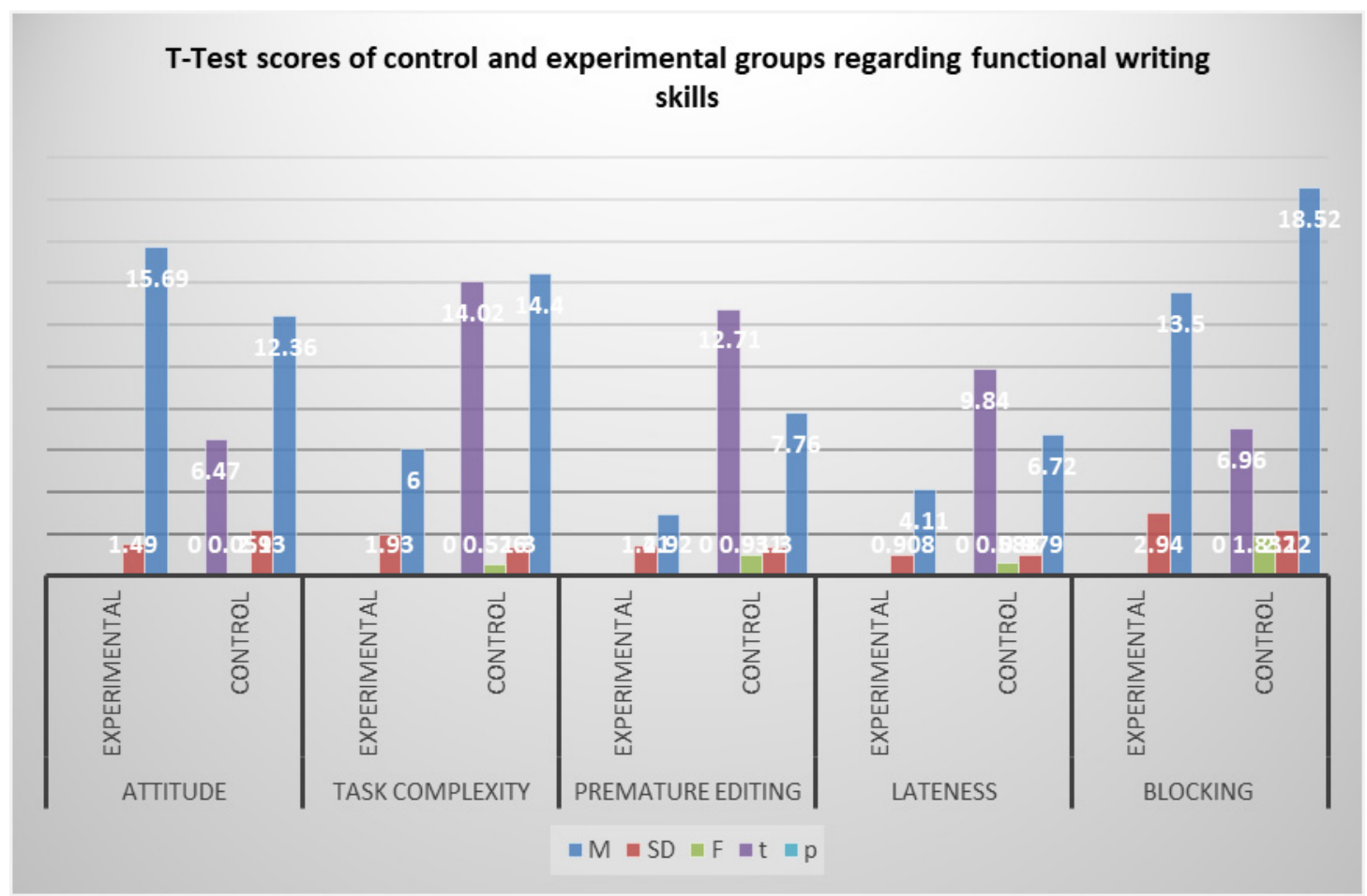

Figure 3. T-Test scores of control and experimental groups regarding functional writing skills

Results obtained support the first hypothesis, it is revealed that there are statistically significant differences in the mean scores of functional writing skills in favor of the experimental group. These results coincide with the results of Lou and Li (2018) study that revealed the positive effects of form-focused instruction in the flipped classroom model on Non-English-Majored Graduates' English Writing. Additionally, the study of Vitanofa and Anwar (2017) has shown similar gains due to implementing flipped classroom as the main teaching technique through the use of graphic organizers toward writing skill at MAN 2 Gresik. Flipped learning takes several tools in teaching, some of which is the use of graphic organizers, video clips, recorder lectures and infographics.

Table 10 shows that implementing flipped leaning practices improved the higher-order thinking skills of the college business students in the experimental group, namely, analyzing, evaluating, and creating. Compared with the gains the control group achieved in the functional writing skills, the students' gain related with levels of higher-order thinking skills is higher. Flipped learning enhances thinking skills of high level due to the practices that increase students' role, motivation and authority in their learning. It also save much of in-class time to be effectively exploited in the classroom discussion, cooperative activities and teamwork.

Table 10. T-Test scores of control and experimental groups regarding higher order thinking skills

\begin{tabular}{lllllll}
\hline HOTs Skills & Group & M & SD & F & t & p \\
\hline Analyzing & Control & 13.20 & 1.84 & 6.343 & 7.24 & .00 \\
& Experimental & 18.38 & 3.08 & & & \\
Evaluating & Control & 12.52 & 2.70 & .001 & 6.26 & .00 \\
& Experimental & 17.50 & 2.96 & & & \\
Creating & Control & 11.76 & 2.20 & 2.809 & 5.18 & .00 \\
& Experimental & 15.65 & 3.07 & & & \\
Total Scores & Control & 37.48 & 5.29 & 3.119 & 6.95 & .00 \\
& Experimental & 51.53 & 8.67 & & & \\
\hline
\end{tabular}




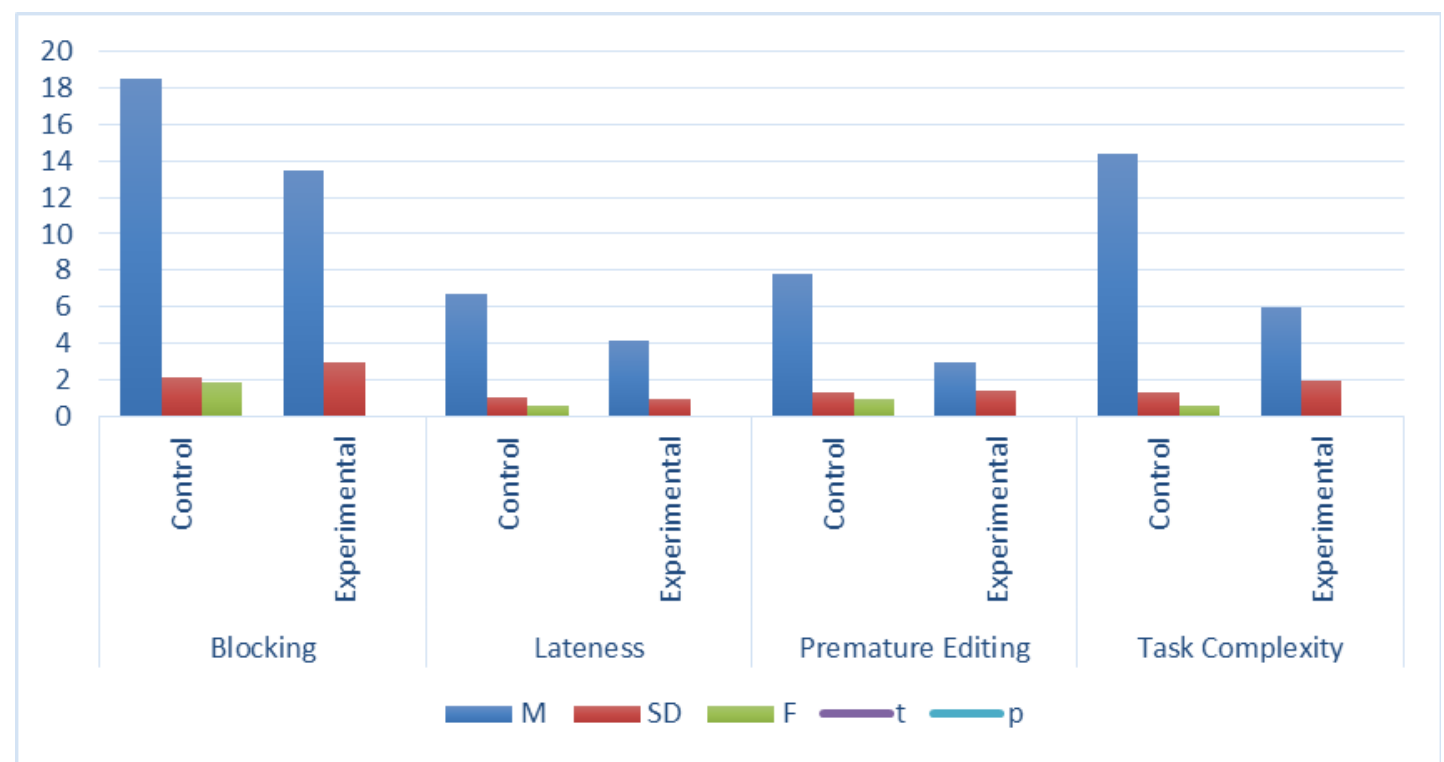

Figure 4. T-Test scores of control and experimental groups regarding higher order thinking skills

Flipped learning approach helps learners to create positive attitudes towards learning, students are motivated to learn, push their learning forward, and to authorize the process of learning. Students' ownership of their learning provide them with opportunities to reflect on both the way they learn and what they lean. Reflection leads to deep thinking on the learning process ending with extending experiences to the surrounding environment and real-life situations. The importance of flipped learning practices to develop higher-order thinking skills is consolidated through the study conducted by Al-Zahrani (2015), it has been indicated that flipped classroom may promote students' creativity, especially with regard to fluency, flexibility and novelty.

Table 11. T-Test scores of control and experimental groups regarding writer's block questionnaire

\begin{tabular}{lllllll}
\hline Writer's block & Group & M & SD & F & t & p \\
\hline Blocking & Control & 18.52 & 2.12 & 1.832 & 6.96 & .00 \\
& Experimental & 13.50 & 2.94 & & & \\
Lateness & Control & 6.72 & .979 & .588 & 9.84 & .00 \\
& Experimental & 4.11 & .908 & & & \\
Premature Editing & Control & 7.76 & 1.30 & .931 & 12.71 & .00 \\
& Experimental & 2.92 & 1.41 & & & \\
Task Complexity & Control & 14.40 & 1.30 & .526 & \multirow{2}{*}{14.02} & .00 \\
& Experimental & 6.00 & 1.93 & & & \\
Totalitude & Control & 12.36 & 2.13 & .059 & 6.47 & .00 \\
& Experimental & 15.69 & 1.49 & & & \\
& Control & 59.76 & 5.13 & .299 & 12.82 & .00
\end{tabular}

Table 11 revealed that the level of writer's block of the experimental group students has decreased relatively compared with the level of control group students. Although experimental group students' performance in functional writing skills and higher-order thinking skills were comparatively high, the levels of writers' block have been alleviated but it was not eradicated. 


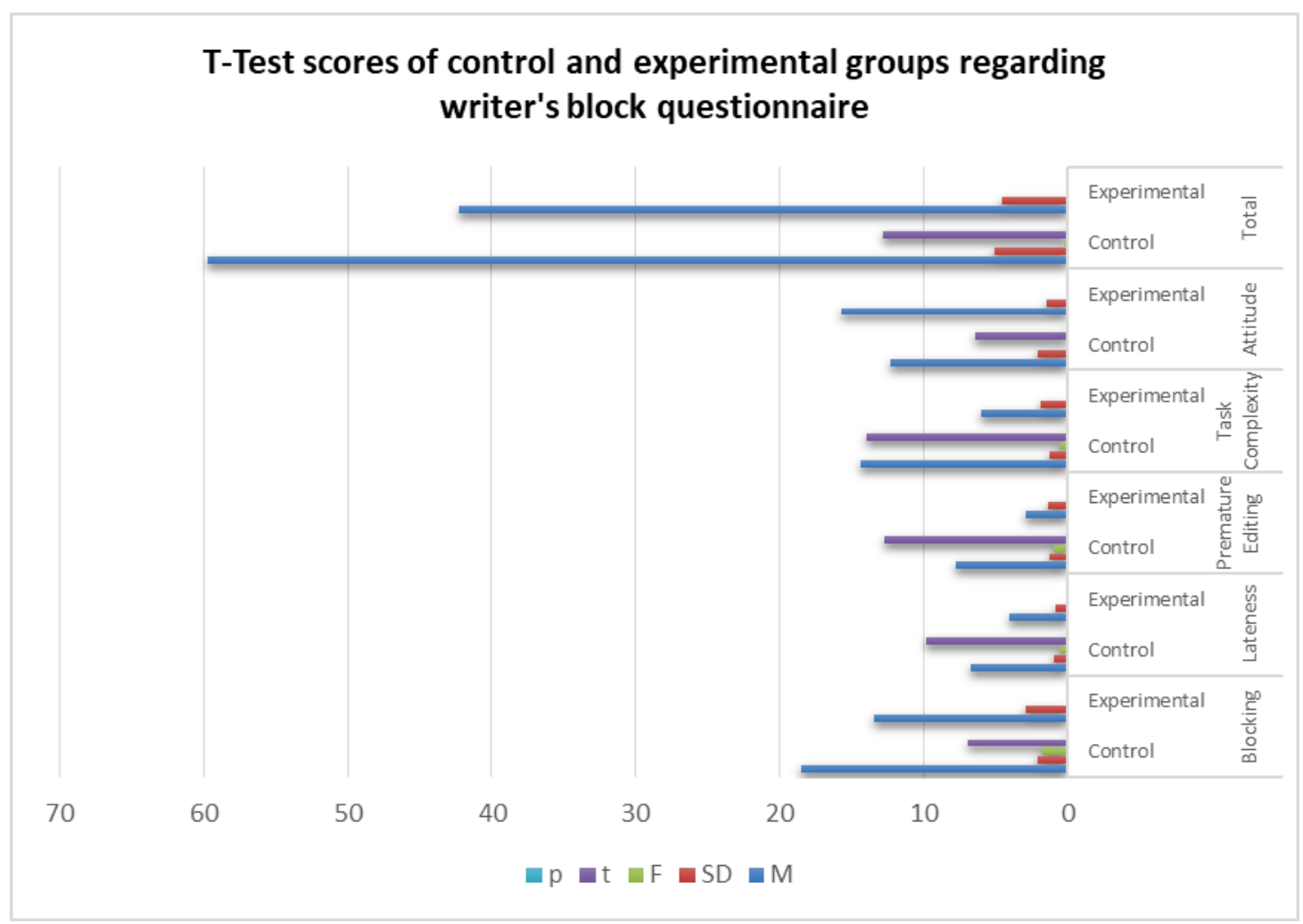

Figure 5. T-Test scores of control and experimental groups regarding writer's block questionnaire

Flipped learning produces active, motivated, and enthusiastic learners. Nouri (2016) emphasizes that the flipped classroom helps active, effective and increased learning especially not only for high achievers but also for low achievers. Therefore, college business students with high levels of writers' block encounter a good aid to get rid of such blockage experiences though teamwork and receiving immediate feedback.

\section{Discussions}

The term flipped classroom has been criticized, is a buzz word and there is no underpinning rationale behind the new teaching model. It is argued that the flipped classroom involves learning through computers independently, outside of the classroom, and interacting with classmates in small groups inside the classroom (Bishop \& Verleger, 2013).

Leveraging flipped learning into the classroom practices has been proved to be effective in developing academic achievement, improving thinking skills, and creating positive attitudes. According to Herreid and Schiller (2013) and Couch (2014), flipped classroom provides more flexibility for students' learning, improves students' academic achievement and allows creative and innovative teaching. Therefore, findings of the current study is not an exception of the general trend, it shows positive impact of flipped learning implementation on developing writing skills, improving higher-order thinking skills, and alleviating levels of writer's block of college students business English.

Flipped learning heals the rift in traditional teaching methods, it saves much more in-class time and teacher's effort for fruitful discussions and interactions that improve skills instead of consuming all the class time on memorizing activities just to keep knowledge to test settings. The effectiveness of flipped learning approach on improving levels of target skills id that it plays an important role on enhancing self-regulated learning in the college ESP classroom. Three successive stages constituting the flipped learning session help learners to succeed in planning and goal setting and activation of knowledge of the task. The second stage - usually takes place inside the class- is teacher monitored, it represents meta-cognitive awareness of different aspects of the task, self or context. Third, self-study and elaboration process is closely related to the effort to control and regulate different aspects of the self or task and context. So far, the three stages of flipped learning coincides with the three phases of self-regulated learning in twin procedures. Finally, the fourth phase of self-regulation learning concerns various kinds of reflections on the self and the task or teaching context. 


\section{Conclusions}

Current evidence suggests that the flipped classroom approach in ESP education overall yields a statistically significant improvement in learner performance compared with traditional teaching methods. University students studying English for Business as a requirement for successful workplace has developed their functional writing skills after intensive training using flipped classroom approach. Needless to say that non-native ESP college students rarely pay due attention to improving their functional writing skills, their interest is to focus on other subjects that are closely related with their major such as marketing and finance. To them, business English is a subsidiary material that adds to their GPA without considering improving language skills. Flipped leaning revealed to represent an effective tool to increase motivation, students' enthusiasm to take full responsibilities of their own learning. In addition, it encourage students to participate actively in pre-class activities and feel ownership of learning.

In addition, thinking skills are considered as "Cinderella skills" as it is the most neglected skills in our educational systems especially developing countries i.e. Africa and MENA. Educational systems in the Middle East focus mainly on pushing forward student's academic achievement especially in high-stake nationwide tests. Additionally, sticking to traditional teaching approaches may impede students from acquiring, improving, and using higher-order thinking skills. According to Leung (2013), Yeung (2012), nurturing higher-order thinking capability is a major goal of the recent curriculum reform and it is crucial for a knowledge-based society.

Implanting flipped classroom principles include setting the scene in advance, the technological infrastructure in schools and colleges in the developing countries still need more support. High performing students demonstrate heavy access of course materials in total as compared to the control group who were not exposed to the online materials and digital tools. These findings speak to the literature not only in supporting the relationship between activity and student success, but also must be considered in the context of the accessibility of course materials or exposure to the online resources whether inside or outside the formal schooling contexts.

Nevertheless, the usefulness of flipped classroom would be exaggerated when quizzes are used at the start of each in-class session. Future research can be conducted to examine the possible effect of specific types of online formative assessment tools on student learning. Future research should also examine the possible impact of gamified flipped classrooms on language learning. Despite the increasing popularity of using game-based learning tools, we very little is understood about how different gamified flipped learning styles may impact student learning. In addition, longitudinal studies should also be conducted to examine whether the flipped classroom approach can foster learning retention over a long period of time.

\section{References}

Abolyosr, M. (1996). Designing a Program for Developing the Writing Skill: an Integrative-Interactive Approach. Unpublished PhD thesis. Qena Faculty of Education. South Valley University.

Ahmed, M. A. A. (2016). The effect of a flipping classroom on writing skill in English as a foreign language and students' attitude towards flipping. US-China Foreign Language, 14(2), 98-114.

Ali, S. N. (2012). Malaysian polytechnic lecturer's teaching practices with ICT utilization to promote higher-order thinking skills. Graduate Theses and Dissertations, Paper 12623. Iowa State University.

Al-Zahrani, A. M. (2015). From passive to active: The impact of the flipped classroom through social learning platforms on higher education students' creative thinking. British Journal of Educational Technology, 46(6), 1133-1148. https://doi.org/10.1111/bjet.12353

Anderson, L. W. J., \& Krawthwohl, D. R. (2001). A taxonomy for learning, teaching, and assessing: A revision of Bloom's taxonomy of educational objectives. New York: Addison Wesley Longman.

Anderson, L. W., Krawthwohl, D. R., Airasian, P. W., Cruikshank, K. A., Mayer, R. E., Pintrinch, P. R., \& Wittrock, M. C. (2001). A taxonomy for learning, teaching and assessing: A revision of Bloom's taxonomy of educational objectives, abridged edition. White Plains, NY: Longman.

Baker-Brodersen, E. M. (1988). Writer's block and a cognitive process model of composing: Recent research and implications for teaching. Retrospective Theses and Dissertations, Iowa State University.

Beekes, W. (2006). The "millionaire" method for encouraging participation. Active Learning in Higher Education, 7(1), 25-36. https://doi.org/10.1177/1469787406061143

Bennett, J., Lubben, F., \& Hogrth, S. (2007). Brining science to life: A synthesis of the research evidence on the effects of context-based and STS approaches to science teaching. Science Education, 91, 347-370. https://doi.org/10.1002/sce.20186 
Bergmann, J., Overmeyer, J., \& Willie, B. (2011). The flipped class: What it is and what it is not. The Daily Riff. Retrieved from http://www.thedailyriff.com/the-flipped-class-converation-689.php

Bergmann, J., \& Sams, A. (2012). Flip your classroom: Reach every student in every class every day. Eugene, or: International Society for Technology in Education.

Bloom, B. S. (Ed.) (1956). Taxonomy of educational objectives: The classification of educational goals, handbook I: Cognitive domain. New York, NY: Longman.

Bloom, B. S., Engelhart, M. D., Furst, E. J., Hill, W. H., \& Krathwohl, D. R. (1971). Taxonomy of educational objectives. Handbook I: Cognitive domain. London: Longman Group Ltd.

Bonwell, C. C. (1996). Enhancing the lecture: revitalizing a traditional format. New Directions for Teaching and Learning, 1996(67), 31-44. https://doi.org/10.1002/t1.37219966706

Chen, M. (2016). Theoretical framework for integrating higher-order thinking into L2 speaking. Theory and Practice in Language Studies, 6(2), 217-226. https://doi.org/10.17507/tpls.0602.01

Chinedu, C. C., Libunao, W. H., Kamen, Y. B., \& Saud, M. S. B. (2014). Implementing Higher Order Thinking Skills in Teaching and Learning of Design and Technology Education. Paper presented at the International Seminar on Technical and Vocational Education, Johor-Malaysia.

Chinedu, C. C., Kamin, Y., \& Olabiyi, O. S. (2015). Strategies for improving higher order thinking skills in teaching and learning of design and technology education. Journal of Technical Education and Training, $7(2), 35-43$.

David, B. (2008). Assessing capability in design and technology: The case for a minimally invasive approach. Design and Technology Education: An International Journal, 12(2).

DeLozier, S. J. \& Rhodes, M. G. (2016). Flipped classrooms: A review of key ideas and recommendations for practice. Educational Psychology Review.

Dewey, J. (1933). How we think: A restatement of the relation of reflective thinking to the educative process. Boston: D. C. Heath and Company.

Emaliana, I. (2017). Teacher-centered or Student-centered Learning Approach to Promote Learning? Journal Social Humanities, 10(2), 59-70. https://doi.org/10.12962/j24433527.v10i2.2161

Fahim, M., \& Masouleh, N. S. (2012). Critical thinking in higher education: A pedagogical look. Theory and Practice in Language Studies, 2(7), 1370-1375. https://doi.org/10.4304/tpls.2.7.1370-1375

Filiz, S., \& Benzet, A. (2018). A content analysis of the studies on the use of flipped classrooms in foreign language education. World Journal of Education, 8(4), 72-86. https://doi.org/10.5430/wje.v8n4p72

Flaherty, A. (2004). The Midnight disease: The drive to write, writer's block, and the creative brain. Boston: Houghton-Mifflin.

Ganapathy, M., \& Kaur, S. (2014). ESL students' perceptions of the use of higher order thinking skills in English language writing. Advances in Language and Literacy Studies, 5(5), 80-87.

Ganapathy, M., Singh, M. K., Kaur, S., \& Kit, L. W., (2017). Promoting higher order thinking skills via teaching practices. 3L: The Southeast Asian Journal of English Language Studies, 23(1), 75-85. https://doi.or $\mathrm{g} / 10.17576 / 3 \mathrm{~L}-2017-2301-06$

Gracey, C. (2004). Mastering the Writing Process. Retrieved from http//www.back2college.com/writprocess.htm

Guven, Ç, G. (2018). The flipped classroom approach in teaching writing: An action research. International Journal of Social Sciences and Education Research, 4(3), 421-432. https://doi.org/10.24289/ijsser.434493

Halliday, M.A.K. (1994). An Introduction to Functional Grammar (2nd ed.). London: Edward Arnold.

Hartnett, Carolyn G. (1997). A Functional Approach to Composition offers an Alternative. Composition Chronicle: Newsletter of Writing Teachers, 10(5), 5-8.

Healy, L. (2010). Ending writer's block. Perspectives: Teaching Legal Research and Writing, 18(2\&3), 151-153.

Heaton .J. B. (1994).Writing English Language Tests. Longman Inc. New York.

Huxham, M. (2005). Learning in lectures Do 'interactive windows' help? Active learning in higher education, 6(1), 17-31. https://doi.org/10.1177/1469787405049943

Hyman, P. (2012). In the year of disruptive education. Communications of the ACM, 55(12), 20-22. 
https://doi.org/10.1145/2330667.2330675

Indrianti. (2012). Developing Student-centered Grammar Materials for Beginners' Level Indonesian. Electronic Journal of Foreign Language Teaching, 9(1), 380-401.

Jansen, G. H. (1984). Writer's block: The cognitive dimension. Journal of Advanced Composition.

Johansen, D., \& Cherry-Paul, S. (2016). Flip your writing workshop: A blended learning approach. Portsmouth, NH: Heinemann.

King, A. (1997). Statewide assessment of listening and verbal communication skills, information literacy skills, and problem-solving skills. Tallahassee: Florida State University.

King, C. (2015). E-learning and flipped instruction integration in business education: A proposed pedagogical model. Journal of Instructional Pedagogies, 16, 1-9.

King, D. (2009). Teaching and learning in context-based chemistry. (PhD Thesis, Queensland University of Technology).

King, D., \& Ritchie, S. (2012). Learning Science through real-world contexts. Second International Handbook of Science Education. Springer International Handbooks of Education, 24, 69-79. https://doi.org/10.100 7/978-1-4020-9041-7_6

King, F. J., Rohani, F., \& Goodson, L. (1997). Statewide assessment of listening and verbal communication skills, information literacy skills, and problem-solving skills. Tallahassee: Florida State University.

King, F., Goodson, L., \& Rohani, F. (2011). Higher order thinking skills: Definitions, strategies, assessment. Center for Advancement of Learning and Assessment. Tallahassee, FL: Florida State University.

Kirk, S. \& Casenove, D. (2015). Flipping the ESP Classroom. Content-based EFL Classes. OnCUE Journal, 9(2), 119-128.

Korbel, T. M. (2001). Strengthening Student Writing Skills. Master of Arts Action Research Project, Saint Xavier University and Skylight professional Development Field-Based Master's program. Available at: http://www.eric.ed.gov.doi. 454546.

Krathwohl, D. R. (2002). A revision of Bloom's taxonomy: An overview. Theory into practice, 41(4), 212-218. https://doi.org/10.1207/s15430421tip4104_2

Kvashnina, O. S., \& Martynko, E. A. (2016). Analyzing the potential of flipped classroom in ESL teaching. iJET, 11(03), 71-73. https://doi.org/10.3991/ijet.v11i03.5309

Lee, A. S. H., \& Wern, L. E. (2011). Involvement of higher order thinking skills within a preparatory course for the Malaysian university English test. The English Teacher, XL, 95-112.

Lee, B. (2017). TELL us ESP in a Flipped Classroom. EURASIA Journal of Mathematics Science and Technology Education, 13(8), 4995-5007. https://doi.org/10.12973/eurasia.2017.00978a

Lee, K. \& Lai, Y. (2017). Facilitating higher-order thinking with the flipped classroom model: A student teacher's experience in a Hong Kong secondary school. Research and Practice in Technology Enhanced Learning, 12(8). https://doi.org/10.1186/s41039-017-0048-6

Lestari, E., \& Widjajakusumah, D. (2009) Students' Self-directed Learning Readiness, Perception toward Student-Centered Learning and Predisposition towards Student-centered Behavior. South East Asian Journal of Medical Education, 3(1).

Leung, L. L. (2013). An inquiry of teachers' perception on the relationship between higher-order thinking nurturing and liberal studies public assessment in Hong Kong. Teachers' Centre Journal, 12, 183-215.

Lewis, A., \& Smith, D. (1993). Defining higher order thinking. Theory into Practice, 32(3), 131-137. https://doi.org/10.1080/00405849309543588

Li, S., \& Suwanthep, J. (2017). Integration of flipped classroom model for EFL speaking. International Journal of Learning and Teaching, 3(2), 118-123. https://doi.org/10.18178/ijlt.3.2.118-123

Liu, Y. (2017). Research on the application of flipped classroom in the teaching reform of business English writing. International Conference on Information, Computer and Education Engineering (ICICEE 2017). https://doi.org/10.12783/dtcse/icicee2017/17150

Lopez, J., \& Whittington, M. S. (2001). Higher-order thinking in a college course: A case study. NACTA Journal, $45(4), 22-29$. 
Lucas, B., Spencer, E., \& Claxton, G. (2012). How to Teach Vocational Education: A Theory of Vocational Pedagogy. London: City \& Guilds Centre for Skills Development.

Majumdar, S. (2015). Emerging Trends in ICT for education \& Training. Retrieved from http://www.unesc o.org/fileadmin/up/emergingtrendsinicteducationandtraining.pdf

Margana, M., \& Widyantoro, A., (2017). Developing English textbooks oriented to higher order thinking skills for students of vocational high schools in Yogyakarta. Journal of Language Teaching and Research, 8(1), 26-38. https://doi.org/10.17507/jltr.0801.04

Marzano, R. J. \& Kendall, J. S. (Eds.) (2006). The new taxonomy of educational objectives. NY: Corwin Press.

McLaughlin, J. E., Roth, M. T., Glatt, D. M., Gharkholonarehe, N., Davidson, C. A., Griffin, L. M., \& Mumper, R. J. (2014). The flipped classroom: A course redesign to foster learning and engagement in a health professions school. Academic Medicine, 89, 236-243. https://doi.org/10.1097/ACM.0000000000000086

Miri, B., David, B.-C., \& Uri, Z. (2007). Purposely teaching for the promotion of higher-order thinking skills: A case of critical thinking. Research in science education, 37(4), 353-369. https://doi.org/10.1007/s1116 5-006-9029-2

Narayanan, S. \& Adithan, M. (2015). Analysis of question papers in Engineering Courses with respect to HOTs (Higher Order Thinking Skills). American Journal of Engineering Education (AJEE), 6(1), 1-10. https://doi.org/10.19030/ajee.v6i1.9247

Nouri, J. (2016). The flipped classroom: for active, effective and increased learning-especially for low achievers. International Journal of Educational Technology in Higher Education, 13-33. https://doi.org/10.1186/s41 239-016-0032-z

O'Flaherty, J., \& Philips, C. (2015). The use of flipped classrooms in higher education: A scoping review. Internet and Higher Education, 25, 85-95. https://doi.org/10.1016/j.iheduc.2015.02.002

Othman, N., \& Mohamad, K. A. (2014). Thinking skill education and transformational progress in Malaysia. International Education Studies, 7(4), 27-28. https://doi.org/10.5539/ies.v7n4p27

Petko, D. (2012). Lectures' pedagogical beliefs and their use of digital media in classrooms: Sharpening the focus of the "will, skill, tool" model and integrating lecture's constructivist orientations. Computers \& Education, 58(4), 1351-1359. https://doi.org/10.1016/j.compedu.2011.12.013

Pickard, M. J. (2007). The new Bloom's taxonomy: An overview for family and consumer sciences. Journal of Family and Consumer Sciences Education, 25(1), 45-55.

Pohl, M. (2001). Learning to Think, Thinking to Learn: Models and Strategies to Devlop a Classroom Culture of Thinking Paperback. UK: awker Brownlow Education Pty Ltd.

Rajendran, N., \& Idris, P. U. P. S. (2008). Teaching \& Acquiring Higher-Order Thinking Skills: Theory \& Practice. Penerbit Universiti Pendidikan Sultan Idris.

Razak, P. A., \& Lee, C. M. (2012). Promoting higher order thinking in Chinese language text via online social network. Journal of Education and Practice, 3(16), 199-209.

Robinson, K., Minkin, L., Bolton, E., French, D., Fryer, L., Greenfield, S., \& Green, L. (1999). All our futures: Creativity. Culture and Education, Report for the Secretary of State for Education.

Roehl, A., Reddy, S. L., \& Shannon, G. J. (2013). The flipped classroom: An opportunity to engage millennial students through active learning strategies. Journal of Family and Consumer Sciences, 105, 44-49. https://doi.org/10.14307/JFCS105.2.12

Rose, M. (1980). Rigid rules, inflexible plans, and the stiffing of language: A cognitivist analysis of writer's block. College Composition and Communication, 31(4), 389-401. https://doi.org/10.2307/356589

Rose, M. (1984). Writer's block: The cognitive dimension (p. 132). Carbondale, Illinois: Southern Illinois University Press.

Rosie, A. (2000). "Deep learning": A dialectical approach drawing on tutor-led web resources. Active Learning in Higher Education, 1(1), 45-59. https://doi.org/10.1177/1469787400001001004

Rowe, M. (1974). Pausing phenomena: Influence on the quality of instruction. Journal of Psycholinguistics Research, 3, 203-224. https://doi.org/10.1007/BF01069238

Saba, N. (2017). Flipped learning: The case of professional English writing course. The IAFOR International 
Conference on Language Learning, Dubai 2017, Official Conference Proceedings.

Salem, A. A. (2008). The Effectiveness of a Proposed Program Based on Using Workshops in Developing the Functional writing Skills of Primary Stage Prospective Teachers of English. MA Thesis in Applied Linguistics, Faculty of Postgraduate Studies in Education, Cairo University.

Salem, A. A. (2013). The Effect of Writer's Workshop Approach to Develop Functional Writing Skills of Primary Stage Pre-Service English Language Teachers in Egypt. International Journal of Applied Linguistics \& English Literature, 5(5), 71-80.

Senske, N. (2017). Five years of flipped classroom: Lessons learned. Architecture Conference Proceedings and Presentations, 109.

Singh, H. S. J.; Singh, Ch. K. S.; Mohtar, T. M. T.; \& Mostafa, N. A. (2017). A review of research on flipped classroom approach for teaching communication skills in English. International Journal of Academic Research in Business and Social Sciences, 7(10), 100-118. https://doi.org/10.6007/IJARBSS/v7-i10/3362

Singh, R. K., Singh, Ch. K., Tunku, M. T., Mostafa, N. A., \& Singh, T. S. (2018). A review of research on the use of higher order thinking skills to teach writing. International Journal of English Linguistics, 8(1), 86-93. https://doi.org/10.5539/ijel.v8n1p86

Stevens, R. (1912). The question as a measure of efficiency in instruction: A critical study of classroom practice. Teachers College Contributions to Education, 48. New York, NY: Teachers College Press.

Stone, B. B. (2012). Flip your classroom to increase active learning and student engagement. A paper presented to 28th Annual Conference on Distance Teaching \& Learning. Retrieved from http://www.uwex.edu/disted/conference.

Straumsheim, C. (2013). Still in favor of the flip. Inside Higher Ed.

Stroupe, R. R. (2006). Integrating critical thinking throughout ESL curricula. TESL Reporter, 39(2), 42-60.

Sun, Y. (2017). Flipping every students? A case study of content-based flipped language classrooms. E-Learning and Digital Media, 14(1-2), 20-37. https://doi.org/10.1177/2042753017692428

Sung, K. (2015). A case study on flipped classroom in an EFL content course. Journal of Multimedia Language Learning, 18(2), 159-187.

Surban, D. (2013). Developing higher-order thinking skills with ICT. Retrieved from http://hdl.handle.net/2139/15701

Tee, T. K., Md Yunos, J., Hassan, R., Yee, M., Hussein, A., \& Mohamad, M. M. (2013). The Level of Higher Order Thinking Skills for Lower Secondary Students in Malaysia. Journal of Research, Policy and Practice of Teachers and Teacher Education, 2(2).

Thomas, A., \& Thorne, G. (2009). How to Increase Higher Order Thinking. Metairie. LA: Center for Development and Learning. Retrieved December 7, 2017, from http://www.cdl.org/resource-library/ articles/HOT.php?type $=$ subject\&id $=18$

Vitanofa, A., \& Anwar, K. (2017). The Effect of Flipped Learning through Graphic Organizers toward Writing Skill at MAN 2 Gresik. Journal of English Teaching, Literature, and Applied Linguistics, 1(2), 37-49.

Voogt, A. (2008). Digital Exhibition and media reviews. Museum Anthropology, 31(1), 57-59. https://doi.org/10. 1111/j.1548-1379.2008.00006.x

Wang, X., \& Wang, J. (2017). New online teaching mode of higher education with information technology. International Journal for Innovation Education and Research, 5(11), 17-27.

Webb, M., \& Doman, E. (2016). Does the flipped classroom lead to increased gains on learning outcomes in ESL/EFL contexts? The CATESOL Journal, 28(1), 39-67.

Werner, L. L., Hanks, B., \& McDowell, C. (2004). Pair-Programming helps female computer science students. Journal of Educational Resources in Computing (JERIC), 4(1), 4. https://doi.org/10.1145/1060071.1060075

White, P. J., Naidu, S., Elizabeth, Y., Short, J. L., McLaughlin, J. E., \& Larson, I. C. (2017). Student engagement with a flipped classroom teaching design affects Pharmacology examination performance in a manner dependent on question type. American Journal of Pharmaceutical Education, 81(9), 10-23. https://doi.org /10.5688/ajpe5931

Wu, K. (1993). Classroom interaction and teacher question revisited. RELC Journal, 24(2), 49-68. 
https://doi.org/10.1177/003368829302400203

Yang, Y. T. \& Gamle, J. (2013). Effective and practical critical thinking enhanced EFL instruction. English Language Teaching Journal, 67(4), 398-412. https://doi.org/10.1093/elt/cct038

Yee, M. H., Jailani, M. Y., Razali, H., Widad, O., \& Tee, T. K. (2010). The Perception of The Level of Higher Order Thinking Skills among Technical Education Students. Paper presented at the International Conference on Social Science and Humanity journal. Faculty of Technical Education, Universiti Tun Hussein Onn Malaysia.

Yee, M. H., Widad, O., Jailani, M. Y., Tee, T. K., Razali, H., \& Mimi Mohaffyza, M. (2011). The level of Marzano higher order thinking skills among technical education students. International Journal of Social Science and Humanity, 1(2), 121.

Yeung, S. Y. (2012). Conceptualizing higher-order thinking for reforming school curriculum and teaching. Hong Kong Teachers' Centre Journal, 11, 131-144.

Young, M. S., Robinson, S., \& Alberts, P. (2009). Students pay attention! Combating the vigilance decrement to improve learning during lectures. Active Learning in Higher Education, 10(1), 41-55. https://doi.org/10.11 $77 / 1469787408100194$

Yunos, J. M., Kiong, T. T., Heong, Y. M., Mohamed, M. M. B., \& Othman, W. B. (2010). The level of higher order thinking skills for lower secondary students in Malaysia. Proceedings of the 1st UPI International Conference on Technical and Vocational Education and Training, 10-11 November 2010, Bandung, Indonesia, 2010.

Zhou, Sh. \& Zhang, T. (2017). Research on the construction of flipped classroom model for English teaching based on SPOC. Revisita de la Facultad de Ingenieria U.C.V., 32(14), 267-273.

Zohar, A., Degani, A. \& Vaaknin, E. (2001). Lecturers' beliefs about low-achieving students and higher order thinking. Teaching and Teacher Education, 17(4), 469-485. https://doi.org/10.1016/S0742-051X(01)00 $007-5$

Zohar, A., \& Dori, Y. J. (2003). Higher order thinking skills and low-achieving students: Are they mutually exclusive? The Journal of the Learning Sciences, 12(2), 145-181. https://doi.org/10.1207/S1532780 9JLS1202_1

\section{Copyrights}

Copyright for this article is retained by the author(s), with first publication rights granted to the journal.

This is an open-access article distributed under the terms and conditions of the Creative Commons Attribution license (http://creativecommons.org/licenses/by/4.0/). 